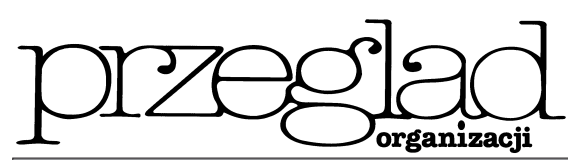

\title{
Budowa systemu zarządzania jakością według norm ISO serif 9000 w ochronie zdrowia
}

https://doi.org/10.33141/po.2005.78.17

Mariusz J. Ligarski

\section{Wprowadzenie}

$\mathbf{R}$ eforma systemu opieki zdrowotnej spowodowała, że placówki ochrony zdrowia zaczęły funkcjonować na rynku konkurencyjnym. Zaczęto poszukiwać możliwości poprawy funkcjonowania organizacji liczac na pozyskanie pacjenta i wzmocnienie swojej pozycji na rynku. Spowodowało to zwrócenie uwagi na zapewnienie jakości w usługach medycznych. W Polsce w latach 90. ub. wieku rozpoczął się program akredytacji szpitali według krajowych standardów jakościowych. Wiodące placówki ochrony zdrowia po uzyskaniu akredytacji poszukiwały dalszych możliwości doskonalenia. Poza tym szukano uniwersalnego narzędzia do poprawy całokształtu działań organizacji, które będzie miało międzynarodowe uznanie. Zwrócono uwagę na normy ISO serii 9000, które to z powodzeniem zaczęły wkraczać w sferę usług. W lutym 2001 roku pierwszy w Polsce szpital zdobył certyfikat systemu jakości według norm ISO serii 9000 [1]. Zachęciło to kolejne organizacje do budowy systemu jakości według standardów międzynarodowych norm jakościowych. W początkowym okresie dużo trudności nastręczało placówkom służby zdrowia dostosowanie wymagań norm do specyfiki usług medycznych. Jednak kolejna aktualizacja norm ISO serii 9000 z roku 2000 zastąiła stare modele ISO 9001
Przegląd Organizacji, Nr 7/8 (786/787), 2005, ss. 66-69 www.przegladorganizacji.pl Towarzystwo Naukowe Organizacji i Kierownictwa (TNOiK)

Tab. 1. Motywy budowy systemu zarządzania jakością w poszczególnych organizacjach

\begin{tabular}{|c|l|}
\hline Organizacja & \multicolumn{1}{|c|}{ Motywy budowy systemu zarządzania jakością } \\
\hline Szpital A & $\begin{array}{l}\text { Zdobycie mocnej pozycji na rynku } \\
\text { Posiadanie standardów jakości według norm ISO } \\
\text { System jako narzędzie do pozyskiwania większej liczby pacjentów z zagranicy }\end{array}$ \\
\hline Szpital B & $\begin{array}{l}\text { Konkurencyjność w stosunku do innych placówek } \\
\text { Wzrost wiarygodności szpitala } \\
\text { Podniesienie jakości usług medycznych } \\
\text { Korzyści marketingowe z certyfikatu }\end{array}$ \\
\hline Zakład opiekuńczy A & $\begin{array}{l}\text { Walka o klienta } \\
\text { Wytworzenie więzi pracownika z zakładem } \\
\text { Uzyskanie dofinansowania do kontraktu }\end{array}$ \\
\hline Zakład opiekuńczy B & $\begin{array}{l}\text { Pozyskanie klienta } \\
\text { Gruntowna reorganizacja placówki } \\
\text { Pozyskanie dodatkowych środków finansowych }\end{array}$ \\
\hline
\end{tabular}

Źródło: opracowanie własne na podstawie wyników badań.

i ISO 9002 z 1994 roku nowym modelem ISO 9001:2000 bazującym na ujęciu procesowym. Stanowiło to kolejny impuls do wykorzystania norm ISO serii $9000 \mathrm{w}$ ochronie zdrowia. Mimo tych sprzyjających okoliczności tylko pojedynczym organizacjom udało się wdrożyć i certyfikować system zarządzania jakością. Powody tego stanu są różnorodne, ze szczególnym naciskiem na sytuację finansową służby zdrowia. Dopiero w ostatnim czasie daje się zauważyć znaczący wzrost liczby placówek ochrony zdrowia, które podjęły się budowy systemu zarządzania jakością. Celem niniejszej pracy jest przedstawienie motywów budowy, przeanalizowanie procesu budowy systemu jakości $\mathrm{z}$ uwzględnieniem trudności tu powstających oraz zaprezentowanie korzyści z wdrożonego już systemu, opierając się na przykładzie czterech organizacji służby zdrowia, które posiadają certyfikowany system zarządzania jakością. Autor wykorzystując wyniki badań własnych przeprowadzonych w latach 2001-2003 , zestawił na potrzeby niniejszej pracy cztery placówki ochrony zdrowia - dwa szpitale i dwa zakłady opiekuńczo-lecznicze*), które wdrożyły system zarządzania jakością według norm ISO serii 9000 . W badanych organizacjach przeprowadzono wywiady, obserwacje i badania ankietowe, których wyniki częściowo wykorzystano w niniejszej pracy. 


\section{Proces budowy systemu zarządzania jakością w ochronie zdrowia}

$\mathbf{P}$

odejmując decyzję o budowie systemu zarządzania jakością według norm ISO serii 9000 kierownictwo czterech badanych placówek chciało zrealizować swoje cele. W przypadku szpitali, które posiadały akredytację według standardów programu akredytacji, chodziło o dalsze doskonalenie sposobu funkcjonowania całej organizacji, wyróżnienie się na rynku oraz uzyskanie mocnej pozycji konkurencyjnej (tabela 1). Dla zakładów opiekuńczo-leczniczych głównym motywem była pobudka finansowa, w okresie tym za wdrożenie systemu uzyskiwało się dodatkowe środki finansowe. Z drugiej strony oczekiwano, że system będzie narzędziem, które pozwoli lepiej pozyskiwać klienta (tabela 1).

Wszystkie badane organizacje zdecydowały się na pozyskanie firm doradczych, które pomogą im zrealizować proces budowy systemu. Wybór organizacji doradczej jest ważnym posunięciem i od właściwego wyboru doradcy zależy wiele w procesie budowy systemu. Dobry doradca to organizacja, która znając znakomicie wymagania normy zechce mocno zaangażować się, we współpracy z przedstawicielami placówki służby zdrowia, w budowę systemu zarządzania jakością, który będzie służył organizacji i będzie wyraźnie wpisany $\mathrm{w}$ jej specyfikę. Budowa takiego systemu wymaga od firmy doradczej zaangażowania wysokiej klasy konsultantów, którzy, poza wiedza, będą umieli umotywować do zmiany, jaką niesie system, pracowników, z którymi przyjdzie im współdziałać. Doradca nie jest $\mathrm{w}$ stanie zbudować dobrego systemu samodzielnie, stąd konieczny jest wybór zespołu ludzi z organizacji, którzy znając dobrze daną organizację będą pod kierunkiem doradcy budowali i wdrażali system. Po podjęciu decyzji i wyborze doradcy zostaje przeprowadzony przegląd (audyt) wstępny. Jest to ocena stanu początkowego organizacji, czyli fundamentu, na którym będzie budowany system. Dobry system zarządzania jakością nie jest rewolucją, ale zmianą ewolucyjną w organizacji. System buduje się opierając na podstawowych zadaniach, jakim służy dana jednostka, na regulacjach prawnych dotyczących jednostki i na dobrych praktykach wypracowanych w danej placówce. Z tego względu przegląd wstępny powinien dostarczyć wielu informacji potrzebnych do określenia stanu początkowego, identyfikując zarówno pozytywne, jak i negatywne zjawiska w organizacji. Pozytywne zostaną wykorzystane do budowy systemu, negatywne budowany system powinien stopniowo eliminować. Kolejnym etapem w procesie budowy są szkolenia. Szkolenia dotyczą zwykle kilku grup w organizacji - najwyższego kierownictwa, zespołu budującego system, pracowników i audytorów wewnętrznych. Każda $\mathrm{z}$ wymienionych grup powinna przejść właściwe dla niej szkolenie, w którym, poza przekazaniem konkretnej wiedzy, należy wpłynąć na pozytywne nastawienie do systemu. Ludzie z natury obawiają się zmian i pozytywna zmiana mentalności w stosunku do systemu jakości powinna wypływać przede wszystkim z działania firmy doradczej. Firma doradcza powinna znaleźć jednak partnera w postaci najwyższego kierownictwa jednostki służby zdrowia. Od zaangażowania najwyższego kierownictwa w poszczególne etapy budowy systemu, a szczególnie w proces szkoleń, zależy powodzenie całego procesu. Kierownictwo powinno dobrać właściwych pracowników do zespołu budującego system, ludzi, którzy są w stanie w zespole pracować dla dobra całej organizacji, nie zapominając o interesach obszarów, które reprezentują. Zwykle pierwszym szkoleniem realizowanym przez doradcę jest szkolenie dla najwyższego kierownictwa. Dobrze przygotowane kierownictwo, w pełni mentalnie przekonane do systemu, powinno sformułować politykę jakości, która zawierać będzie strategię organizacji w kontekście jakości. Bardzo ważne jest szkolenie i przygotowanie do wdrażania systemu zespołu budującego system. Zespół ten pod kierownictwem doradcy będzie identyfikował procesy, działania zachodzące w organizacji, będzie tworzył i wdrażał konieczną dokumentację. Istotne jest szkolenie pracowników; szkolenie dla tej grupy ma na celu, poza przekazaniem podstawowych informacji o systemie, przekonać do pracy w systemie, pokazać, że system jest naturalnym zjawiskiem w ich pracy. Z badań ankietowych wynika, że w badanych organizacjach okoto $70 \%$ pracowników zostało przeszkolonych $\mathrm{w}$ ramach systemu jakości. Jest to przyzwoity wynik, biorąc pod uwagę sektor innych usług; w analizowanych organizacjach pozytywnie do systemu odnosiła się zdecydowana większość poddanych badaniom. Ale pozostaje 30\% pracowników, którzy nie uczestniczyli w żadnych szkoleniach w tym zakresie; ludzie ci mają bardzo mała wiedzę o systemie i najpewniej ich nastawienie do systemu nie jest najlepsze. Jest to zagrożenie dla systemu, ich niewiedza i brak przekonania może wpłynać na negatywne nastawienie do systemu i blokować wdrażanie, a po wdrożeniu może to być słabe ogniwo $\mathrm{w}$ funkcjonujacym już systemie. Ostatnim z grupy szkoleń jest szkolenie dla audytorów wewnętrznych. Audytorzy wewnętrzni to pracownicy organizacji, którzy po odpowiednim przygotowaniu mają poddawać system cyklicznym badaniom $\mathrm{w}$ celu potwierdzenia zgodności z wymaganiami normy; mają poszukiwać możliwości rozwoju i doskonalenia systemu oraz identyfikować niezgodności w systemie. Z tego względu ważny jest odpowiedni dobór zespołu audytorów oraz ich dobre przygotowanie do zadań, które mają pełnić. Kolejnym etapem w budowie systemu jest etap opracowania i wdrożenia dokumentacji. Jest to etap, z którym wszystkie badane organizacje miały problemy. Z jednej strony są wymagania normy ISO serii 9000 , $\mathrm{z}$ drugiej, dokumentacja stricte medyczna, w przypadku szpitali jeszcze dokumentacja, którą opracowano na potrzeby akredytacji. W tym momencie ujawnia się „jakość" doradcy, jego doświadczenie, umiejętność wypracowania kompromisu, opisania tego, co niezbędne. Ogólnym zarzutem w stosunku do systemu jakości według norm ISO serii 9000 jest tworzenie dużej liczby dokumentów. Tymczasem nowy model wymagań systemu - norma ISO 9001:2000 - wymaga tylko księgi jakości, czyli nadrzędnego dokumentu opisującego system oraz pewnej liczby procedur. To organizacja określa, jakie procesy w niej zachodzą, to organizacja tworzy koncepcję potrzebnej jej dokumentacji. Na tym etapie konieczny jest spory wysiłek intelektualny doradcy z zespołem budującym system, żeby 
zaprojektować tyle dokumentów, aby system mógł sprawnie funkcjonować i służyć organizacji. W niektórych badanych organizacjach zwrócono uwagę na niewystarczające zaangażowanie pracowników w tworzenie dokumentacji. Dokumentacja jest opracowywana przez różnych wyznaczonych pracowników lub ich grupy. Zachodzi zwykle konieczność włączenia większej liczby pracowników, niż tylko zespół budujący system i tutaj uwidacznia się konieczność wcześniejszego przekonania do systemu i przekazania niezbędnej o nim wiedzy. Niewłaściwe przygotowanie tej grupy ludzi skutkuje tym, że przy zwiększonej liczbie obowiązków, jaka zwykle ma miejsce podczas budowy systemu, ludzie ci niechętnie i bez przekonania przystępuja do tworzenia zleconej im dokumentacji. Trudno oczekiwać, że to, co stworzą, będzie współgrało z nawet najlepiej opracowaną dokumentacją przez zespół ds. budowy systemu. Wdrażanie dokumentacji jest procesem realizowanym w różny sposób, w zależności od firmy doradczej. Jedne organizacje wdrażają w życie dany dokument zaraz po opracowaniu, inne starają się wdrożyć jednorazowo większą grupę dokumentów lub nawet ich całość. Dokumenty muszą być sprawdzone w praktyce, przetestowane w warunkach rzeczywistych, tylko wtedy można bowiem wykryć problemy i później wprowadzić konieczne modyfikacje. $\mathrm{Na}$ tym etapie ważne jest, aby zapewnić wystarczającą ilość czasu na testowanie i wprowadzanie korekt w dokumentacji, gdyż tylko w takim przypadku możemy opracować dokumentację dla organizacji, która będzie systematyzować rzeczywiste działania zachodzace w organizacji. Równolegle $\mathrm{z}$ wdrażaniem dokumentacji ma miejsce wdrażanie całego sytemu w praktyce danej organizacji. Kolejnym etapem budowy systemu jest przeprowadzenie audytów wewnętrznych. Dobrze przygotowani audytorzy wewnętrzni będą w stanie dostarczyć dużo informacji o systemie funkcjonującym w poszczególnych komórkach organizacyj- nych. Naturalnym zjawiskiem jest fakt, że nie wszystko i nie od początku będzie funkcjonować idealnie. To właśnie informacje $\mathrm{z}$ audytów, postawa współpracy audytorów ma na celu wprowadzenie korekt tam, gdzie to konieczne. Jeśli system w opinii zainteresowanych i firmy doradczej już funkcjonuje i jest modyfikowany, przychodzi czas na poddanie go audytowi certyfikacyjnemu. Ważny jest odpowiedni wybór jednostki certyfikującej. Znalezienie jednostki certyfikującej, która będzie współpracowała z organizacją w celu rozwoju i doskonalenia systemu, a nie tylko identyfikowała niezgodności podczas audytu. Właściwa certyfikacja polega na badaniu systemu jakości w poszczególnych obszarach i odpowiedzi, czy są zgodne z wymaganiami odpowiedniego modelu normy. Jeśli audytorzy firmy certyfikującej wykryją niezgodności podczas certyfikacji, organizacja ma czas na ich usunięcie, audytorzy badają skuteczność usunięcia niezgodności i przyznawany jest certyfikat jakości na trzy lata. Korzyści identyfikowane przez poszczególne organizacje po wdrożeniu i certyfikacji systemu zestawiono w tabeli 2.

\section{Podsumowanie}

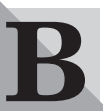
adane organizacje: dwa szpitale i dwa zakłady opiekuńczo-lecznicze podjęły świadomie decyzje o budowie systemu zarządzania jakością według norm ISO serii 9000 licząc na uzyskanie określonych korzyści. Wszystkie cztery organizacje korzystały z pomocy doradczej przy budowie systemu zarządzania jakością. Główne problemy, jakie pojawiły się na etapie budowy systemu, to trudności z opracowaniem dokumentacji i opór ludzki w stosunku do zmiany, jaką niesie wdrażany system. Przyczyn tych problemów należy upatrywać przede wszystkim w niewystarczajacym przekonaniu pracowników do systemu oraz trudnościach związanych $\mathrm{z}$ dostosowa-

Tab. 2. Korzyści z wdrożonego systemu zarządzania jakością identyfikowane w poszczególnych organizacjach

\begin{tabular}{|c|l|}
\hline Organizacja & \multicolumn{1}{|c|}{ Korzyści z wdrożonego systemu zarządzania jakością } \\
\hline Szpital A & $\begin{array}{l}\text { Sformalizowanie wszystkich procesów w szpitalu } \\
\text { Zwiększenie świadomości wśród pracowników } \\
\text { Jednoznaczne określenie odpowiedzialności i uprawnień } \\
\text { Korzyści marketingowe }\end{array}$ \\
\hline Szpital B & $\begin{array}{l}\text { Standaryzacja metod pracy } \\
\text { Poprawa komunikacji w szpitalu } \\
\text { Zwiększenie motywacji personelu } \\
\text { Przepustka do nawiązania współpracy z kontrahentami zagranicznymi }\end{array}$ \\
\hline Zakład opiekuńczy A & $\begin{array}{l}\text { Poprawa organizacji pracy } \\
\text { Jednoznaczne określenie zakresów obowiązków i uprawnień } \\
\text { Sprawniejsza komunikacja } \\
\text { Korzyści zewnętrzne }\end{array}$ \\
\hline Zakład opiekuńczy B & $\begin{array}{l}\text { Lepsza organizacja pracy } \\
\text { Przejrzyste określenie kompetencji i uprawnień } \\
\text { Szybka i sprawniejsza komunikacja } \\
\text { Aspekty marketingowe }\end{array}$ \\
\hline
\end{tabular}

Źródło: opracowanie własne na podstawie wyników badań. 
niem wymagań systemu do specyfiki placówki służby zdrowia. W dwóch szpitalach pojawił się problem współistnienia dwóch systemów - systemu opracowanego na potrzeby akredytacji i systemu zarządzania jakością według norm ISO serii 9000 . W czasie prac okazało się, że systemy te w pewnych płaszczyznach przenikają się i istnieje możliwość wykorzystania tego, co opracowano w pierwszym systemie na potrzeby drugiego systemu. Mimo tych problemów proces budowy zakończył się we wszystkich przypadkach zdecydowanym sukcesem. Wszystkie placówki stwierdziły, że system spowodował standaryzację metod pracy i wpłynął na poprawę organizacji pracy (tabela 2). Zwrócono uwagę na jednoznaczne określenie odpowiedzialności i uprawnień oraz poprawę komunikacji wewnętrznej. Każda organizacja dostrzega korzyści zewnętrzne płynące $\mathrm{z}$ systemu (tabela 2). Przeprowadzone badania wykazały, że zdecydowana większość pracowników pozytywnie ocenia system i widzi w związku z jego funkcjonowaniem wymierne korzyści. Taki efekt w dużej mierze jest uzależniony od postawy kierownictwa badanych organizacji; kierownictwo wykazało duże zaangażowanie w budowę systemu i włożyło znaczacy osobisty wkład we wdrożenie systemu. W badanych organizacjach pozytywnie oceniono otrzymana pomoc ze strony doradców i w tym również należy upatrywać sukces całego procesu wdrożenia. Funkcjonowanie systemu zarządzania jakością zależy w dużej mierze od sposobu jego budowy. Jeśli proces budowy zostanie sprawnie zrealizowany, ludzie na etapie budowy przekonają się do systemu, to system będzie skutecznie funkcjonował po certyfikacji. Jeśli natomiast popełni się istotne błędy na etapie budowy, to błędy te będzie trudno usu- nąc na etapie funkcjonowania systemu. Przedstawiony przykład czterech organizacji służby zdrowia, które poprawnie zrealizowały proces budowy systemu uzyskując określone korzyści, przemawia za wykorzystaniem systemu zarządzania jakością według norm ISO serii $9000 \mathrm{w}$ ochronie zdrowia. Biorąc pod uwage organizacje, w których wcześniej wdrożono system zapewnienia jakości według standardów akredytacyjnych należy stwierdzić, że system zarządzania jakością według norm ISO serii 9000 jest systemem komplementarnym w stosunku do pierwszego. Oba systemy nie wykluczają się wzajemnie, co więcej, mają wspólne elementy i w organizacjach, które zdecydowały się na budowę ich obu obejmują całokształt zagadnień dotyczących jakości. System akredytacji dotyka organizację przede wszystkim w sferze medycznej i tutaj określa standardy jakościowe. System zarządzania jakością jest typowym systemem w sferze zarządzania, który określa całokształt procesów zarządczych w kontekście satysfakcji klienta.

dr inż. Mariusz J. Ligarski

Katedra Zarządzania Jakością Procesów

i Produktów, Wydział Organizacji i Zarządzania Politechnika Śląska

\footnotetext{
*) W pracy nie zostaną podane nazwy placówek ochrony zdrowia, dla rozróżnienia będą wykorzystywane określenia szpital A, szpital B, zakład opiekuńczy A, zakład opiekuńczy B.
}

\section{BIBLIOGRAFIA}

[1] LIGARSKI M.J., Normy ISO serii 9000 w polskich organizacjach - historia i perspektywy, „Zeszyty Naukowe Politechniki Śląskiej”, seria „Organizacja i Zarządzanie”, z. 12, Gliwice 2002, s. 153-159. 